\title{
Reduced $\beta$ adrenoceptor density in vivo in human lung tumours: a preliminary study with positron emission tomography
}

\author{
F Qing, M J Hayes, C G Rhodes, T Krausz, S W Fountain, $M$ M Burke, T Jones, \\ J M B Hughes
}

\begin{abstract}
Background - Reduced $\beta$ adrenergic receptor density in tumours has been reported in previous in vitro studies. The aim of the present study was to assess whether this occurs in vivo.

Methods - Pulmonary $\beta$ adrenoceptors were imaged and quantified in vivo using positron emission tomography (PET) and the $\beta$ antagonist radioligand (S)$\left[{ }^{11}\right.$ C]CGP-12177 in five men with lung tumours of mean age 58 years (range 4268). The histology of the tumours was squamous cell carcinoma in two cases, adenocarcinoma in one, carcinoid tumour in one, and large cell carcinoma in one. The regional blood volume and extravascular tissue density were also measured using PET. Regions of interest were drawn for both non-tumour and tumour lung tissue.
\end{abstract}

Department of

Medicine (Respiratory

Division)

$F$ Qing

M J Hayes

J M B Hughes

Department of

Histopathology

T Krausz

Royal Postgraduate

Medical School,

Hammersmith

Hospital, Du Cane

Road, London

W12 ONN, UK

MRC Clinical Sciences

Centre, Cyclotron

Unit, Hammersmith

Hospital, London, UK

C G Rhodes

$\mathrm{T}$ Jones

Thoracic Surgical

Unit, Harefield

Hospital, Harefield,

Middlesex

UB9 6JH, UK

$S$ W Fountain

Department of

Histopathology, Mount

Vernon Hospital,

Middlesex, UK

M M Burke

Correspondence to:

Professor J M B Hughes.

Received 21 December 1994

Returned to authors

7 March 1995

Revised version received

14 November 1995

14 November 1995
Accepted for publication

Accepted for publicary
Results - The mean (SD) blood volume was $0.142(0.025) \mathrm{ml} / \mathrm{ml}$ in tumour regions and $0.108(0.010) \mathrm{ml} / \mathrm{ml}$ in normal lung regions - a difference of $31 \%$. Mean (SD) extravascular tissue density was 0.653 $(0.133) \mathrm{g} / \mathrm{ml}$ in tumour regions, substantially higher than in normal lung regions $(0 \cdot 157(0 \cdot 021) \mathrm{g} / \mathrm{ml})$. On the contrary, $\beta$ receptor density was $5 \cdot 1(1 \cdot 8) \mathrm{pmol} / \mathrm{g}$ in tumour regions, lower than the value of $9.9(1.6) \mathrm{pmol} / \mathrm{g}$ found in adjacent normal lung - a difference of $48 \%$.

Conclusions - In vivo $\beta$ adrenoceptor density is reduced in human lung tumours.

(Thorax 1996;51:727-732)

Keywords: $\beta$ adrenergic receptors, neoplasms, positron emission tomography.

The $\beta$ adrenergic system has been shown to differentiation. ${ }^{2}$ In previous in vitro studies activation of the $\beta$ adrenergic system has been reported to promote the differentiation of the human promonocytic cell line into monocyticlike cells ${ }^{3}$ and to induce the differentiation of promyelocytic cells. ${ }^{4}$ In addition, in vivo administration of the $\beta$ agonist isoprenaline in rat resulted in a suppression of the growth of the C-6 glioma tumour, ${ }^{1}$ while ablation of the sympathetic nerve system augmented tumour growth. ${ }^{5}$ Furthermore, this suppressive response of isoprenaline was proportional to the $\beta$ adrenergic receptor density on the tumour cell surface. ${ }^{6}$ Reduced density of $\beta$ adrenergic play a modulatory role in cell growth ${ }^{1}$ and receptors in tumour tissue has been previously reported in in vitro studies. Mouse lymphocytic leukaemia cells have been shown to have fewer $\beta$ adrenoceptors per cell and a smaller fraction of these receptors are functionally active cell surface receptors. ${ }^{7}$ In lung, mouse neoplastic cells contained fewer $\beta$ adrenoceptors and produced less cAMP in response to isoprenaline. ${ }^{8}$ In human lung in vitro $\beta$ receptors were also decreased in cancer tissue. ${ }^{9}$

Positron emission tomography (PET) is a specialised branch of medical imaging whose accuracy and specificity merit the term "in vivo autoradiography". It has opened up a new field of study in oncology by providing information on glucose metabolism, oxygen utilisation, tumour hypoxia, haemodynamics, and protein and DNA synthesis. ${ }^{10}$ When used with suitable radiolabelled ligands, PET can also be used to determine receptor density in vivo. With fluorine-18 labelled fluoroestradiol, PET has been used to study oestrogen receptors in patients with breast cancer to assist in evaluation of metastatic or recurrent lesions and, more important, to predict the response of individual patients to anti-oestrogen therapy. ${ }^{11}$ In view of the potential therapeutic possibility of modulating the sympathetic nervous system to control tumour growth we have used PET and carbon-11 labelled (S)-CGP-12177 to measure pulmonary $\beta$ adrenoceptor density in vivo in patients with lung cancer to assess the degree to which the in vitro differences in density of $\beta$ receptors between tumour and normal lung occur in vivo.

\section{Methods}

PATIENTS

Five men of mean age 58 years (range 42-68) with lung tumours were investigated. Their details are summarised in the table. None of the patients was taking $\beta$ agonists, $\beta$ antagonists, or any other drugs that might interfere with the sympathetic nervous system. All patients gave written informed consent to the protocol which was approved by the Hammersmith Hospital Research ethics committee and the United Kingdom Administration of Radioactive Substances advisory committee.

\section{PATHOLOGICAL ASSESSMENT}

Resected tumours were available for examination in cases 1,3 , and 4 and biopsy tissue only was available in cases 2 and 5 . At bronchoscopy a polypoid endobronchial 
Histopathological findings

\begin{tabular}{|c|c|c|c|c|c|c|}
\hline Patient no. & Age (years) & Diagnosis & Differentiation & Inflammation & Necrosis & Fibrosis \\
\hline $\begin{array}{l}1 \\
2 \\
3 \\
4 \\
5\end{array}$ & $\begin{array}{l}60 \\
64 \\
58 \\
42 \\
68\end{array}$ & $\begin{array}{l}\text { Squamous cell carcinoma } \\
\text { Squamous cell carcinoma } \\
\text { Adenocarcinoma } \\
\text { Carcinoid tumour } \\
\text { Large cell carcinoma } †\end{array}$ & $\begin{array}{l}\text { Moderate } \\
\text { Poor } \\
\text { Moderate } \\
\text { NA } \\
\text { Poor }\end{array}$ & $\begin{array}{l}++ \\
\text { NA, Bx only* } \\
+++ \\
- \\
\text { NA, Bx only }\end{array}$ & $\begin{array}{l}\stackrel{+}{\mathrm{NA}}, \mathrm{Bx} \text { only } \\
- \\
- \\
\mathrm{NA}, \mathrm{Bx} \text { only }\end{array}$ & $\begin{array}{l}\stackrel{+}{N} \mathrm{~A}, \mathrm{Bx} \text { only } \\
- \\
- \\
\text { NA, Bx only }\end{array}$ \\
\hline
\end{tabular}

$\mathrm{NA}=$ not applicable; $\mathrm{Bx}=$ biopsy $-=$ none; $+=$ occasional $/$ small foci $++=$ several $/$ large foci; $+++=$ extensive.

* Bronchial and thyroid biopsy specimens only. No thoracotomy followed due to the metastasis in the thyroid.

† Bronchial biopsies and brushing and adrenal biopsy specimens only. No thoracotomy performed due to the metastasis.

tumour was seen in case 5 and, although brushings showed large cell carcinoma, a biopsy was non-diagnostic. Subsequently, a needle biopsy of an adrenal mass showed carcinoma. These findings were felt sufficient to justify a diagnosis of primary lung carcinoma rather than pulmonary metastases.

The grade of differentiation of the malignant tumours was given as mild, moderate, or poor. The carcinoid tumour in case 4 was not graded. Histological slides of the three resected tumours were assessed on the basis of the number and size of the foci for necrosis, inflammation, and fibrosis. Occasional/small foci were scored as + , several foci/large foci as ++ , and extensive as +++ . The small volumes of tumour in the biopsy specimens from cases 2 and 5 were not considered representative and were therefore not quantified.

\section{PET SCANNING}

PET scans were performed using an ECAT 931-08/12, 15-plane positron camera (Siemens/
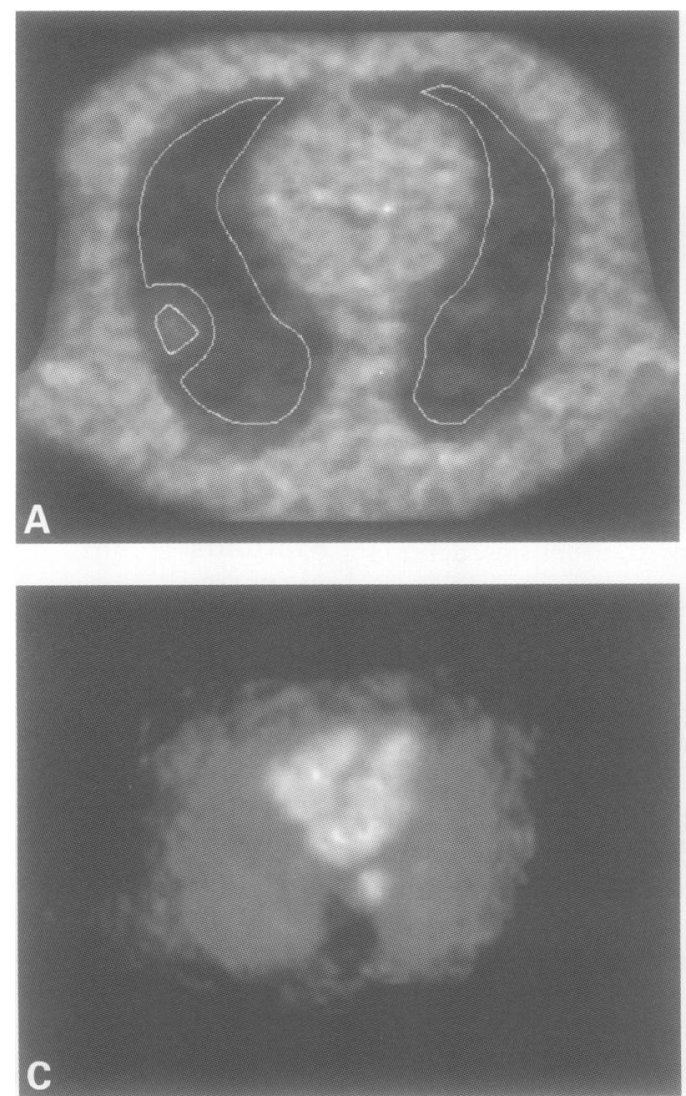

CTI Inc, Knoxville, Tennessee, USA) as previously described. ${ }^{12}$ Each plane has a slice thickness of $6.6 \mathrm{~mm}$ full width at half maximum; the total thickness of lung imaged in the transaxial direction is $10.8 \mathrm{~cm}$. PET scanning consisted of (1) transmission, (2) $\mathrm{C}^{15} \mathrm{O}$ emission and (3) (S)- $\left[{ }^{11} \mathrm{C}\right]$ CGP-12177 dynamic emission scans.

The patients lay supine on the scanning table. A venous cannula was inserted into a forearm vein for blood sampling and a second venous cannula was inserted into the other arm for the tracer infusion. Arterial blood pressure and electrocardiography were recorded every 15 minutes throughout the study.

\section{Transmission scan}

The scan information was recorded for a 20 minute period during the exposure of a ring source of positron emitting ${ }^{68} \mathrm{Ge} /{ }^{68} \mathrm{Ga}$ that encircles the subject. These data were used for attenuation correction of all subsequent emission data and also provided images of the lung density distribution, total density (vascular plus
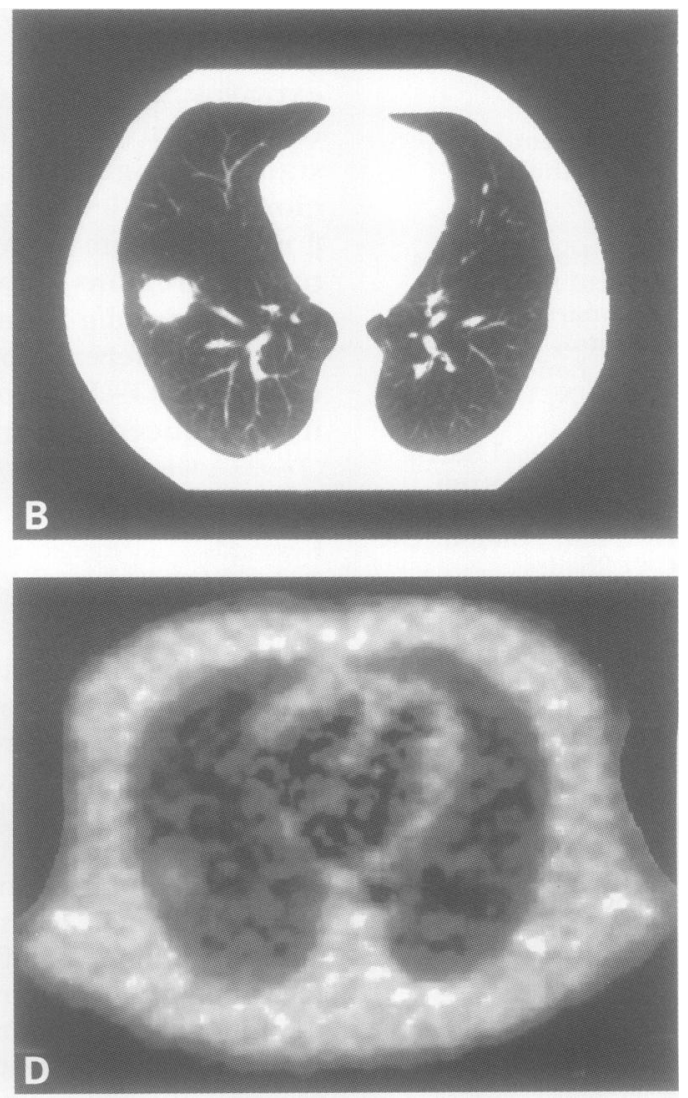

Figure 1 (A) PET image of total lung density from case 3. Regions of interest were drawn on this image for the normal lung regions as well as for the tumour, identified as a high density area in the right peripheral field. (B) CT scan of a plane close to that shown in (A). (C) PET image of regional pulmonary blood volume. (D) PET image of extravascular tissue density. 
extravascular, $\mathrm{g} / \mathrm{ml}$ [g lung/ml thoracic volume]) (fig 1A). A computed tomographic (CT) scan (fig 1B) is also provided for comparison.

\section{$C^{15} \mathrm{O}$ emission scan}

To obtain regional blood volume $(\mathrm{ml} / \mathrm{ml}[\mathrm{ml}$ blood/ml thoracic volume]) (fig 1C) a six minute emission scan was performed five minutes after the start of a four minute inhalation of oxygen-15 labelled carbon monoxide $\left(\mathrm{C}^{15} \mathrm{O}\right)$ in air. $\mathrm{C}^{15} \mathrm{O}$ was administered at a concentration of $3 \mathrm{MBq} / \mathrm{ml}$ and a flow rate of $500 \mathrm{ml} / \mathrm{min}$. $\mathrm{C}^{15} \mathrm{O}$ combines with haemoglobin to form ${ }^{15} \mathrm{O}$ carboxyhaemoglobin in the red blood cells of the lung capillaries. Blood samples were taken $0,2,4$, and 6 minutes after the start of the $\mathrm{C}^{15} \mathrm{O}$ scan to relate vascular radioactivity to the equilibrium images of the $\mathrm{C}^{15} \mathrm{O}$ distribution, thereby allowing the calculation of regional pulmonary blood volume, to be used later in the calculation of receptor density. Values of regional blood density ( $\mathrm{g}$ blood $/ \mathrm{ml}$ thorax) were obtained by multiplying the regional blood volume by 1.06 (whole blood density). Quantitative images of pulmonary extravascular tissue density ( $\mathrm{g} / \mathrm{ml}$ ) (fig 1D) were then calculated by subtracting blood density from the normalised transmission scan as previously described. ${ }^{13}$

\section{S- $\left[{ }^{11} C\right]$ CGP-12177 dynamic emission scan} (S)-CGP-12177 [(3'-tert-butylamino-2'-hydroxypropoxy)-benzimidazol-2-one] was asymmetrically synthesised and labelled with the short lived positron emitting radionuclide carbon-11 (half life $=20.4$ minutes) on site. ${ }^{14}(\mathrm{~S})$ $\left[{ }^{11} \mathrm{C}\right] \mathrm{CGP}-12177$ produced by this method exceeded $99 \%$ chemical and radiochemical purity. Measurement of pulmonary $\beta$ adrenoceptor density was performed using a modification of the double injection method of Delforge et al. ${ }^{15}$ A high specific activity (S)-[ $\left.{ }^{11} \mathrm{C}\right] \mathrm{CGP}-12177$ preparation ( 185 MBq (S)-[ $\left.{ }^{11} \mathrm{C}\right] \mathrm{CGP}-12177$ in $3 \mu \mathrm{g}$ cold (S)-CGP-12177) was given intravenously over two minutes followed 30 minutes later by a second injection of (S)-[ $\left.{ }^{11} \mathrm{C}\right] \mathrm{CGP}$ 12177 with a lower specific activity ( $370 \mathrm{MBq}$ (S)-[ $\left.{ }^{11} \mathrm{C}\right] \mathrm{CGP}-12177$ in $25 \mu \mathrm{g}$ cold (S)-CGP-12177). Dynamic emission scanning comprising 55 frames started at the time of the first injection and continued for 75 minutes. A representative image of the (S)$\left[{ }^{11} \mathrm{C}\right] \mathrm{CGP}-12177$ uptake is shown in fig 2 .

\section{CALCULATION OF $\beta$ ADRENOCEPTOR DENSITY}

Images were analysed on SUN work stations by use of Analyze image analysis ${ }^{16}$ and the Matlab (The MathWorks Inc, Natick, Massachusetts, USA) mathematical software package. Regions of interest (ROIs) for the normal lung regions and for the tumour, the latter identified as high density areas, were drawn on the transmission images. In the 15 planes scanned the most caudal plane was selected from the second plane above the diaphragm. To generate pulmonary tissue tracer time/activity curves ROIs were projected onto the dynamic

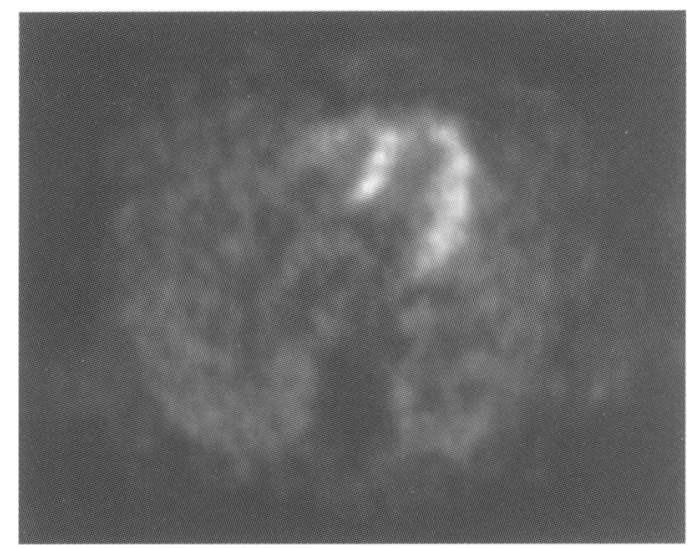

Figure 2 Quantitative image of $\beta$ adrenoceptor binding (pmol/ml thorax) obtained by adding the dynamic time frame images recorded between 10 and 30 minutes following the first (S)- $\left[^{11}\right.$ CJCGP 12177 injection. The signal from the lung is low relative to the heart (top right) because of the low tissue occupancy of the lung (see fig 1(D)). Visual discrimination between tumour and normal lung in this image is poor because of the similar level of uptake (the tumour uptake is only twice that of lung) and regional statistical fluctuation.

(S)- $\left[{ }^{11} \mathrm{C}\right] \mathrm{CGP}-12177$ images. The mean tracer activity in serial lung planes (craniocaudal) was calculated and plotted against time. The extravascular tissue tracer time/activity curve was obtained by subtracting the pulmonary vascular (S)- $\left[{ }^{11} \mathrm{C}\right]$ CGP-12177 time/activity curve (calculated from the $\mathrm{C}^{15} \mathrm{O}$ blood volume data and (S)- $\left[{ }^{11} \mathrm{C}\right] \mathrm{CGP}-12177$ activity in the venous blood samples) from the regional (S)$\left[{ }^{11} \mathrm{C}\right] \mathrm{CGP}-12177$ time/activity curve. A graphical approach based on that originally proposed by Delforge et al for use in the heart ${ }^{15}$ was used to calculate the density of pulmonary $\beta$ adrenoceptors in each ROI, taking into account the total amount of cold ligand in both injections. This technique was further modified to express $\beta$ adrenoceptor density as $\mathrm{pmol} / \mathrm{g}$ (pmol per gram of tissue) by normalising the $\beta$ adrenoceptor density to the local value of extravascular tissue density. The $\beta$ adrenoceptor density in $\operatorname{lung}^{17}$ and heart ${ }^{18}$ estimated using this PET approach has been shown to be correlated with the $\beta$ receptor density determined with classic in vitro measurement (radioligand binding assay).

\section{STATISTICAL ANALYSIS}

Data are presented as means (SD). Paired $t$ tests were used to compare the values between tumour and normal regions. A value of $p<0.05$ was considered statistically significant.

\section{Results}

The histopathological findings are given in the table.

PULMONARY BLOOD VOLUME

In each subject the regional blood volume was higher in tumour regions than in normal lung regions. For the group as a whole the blood volume was $0.142(0.025) \mathrm{ml} / \mathrm{ml}$ in tumour regions and $0 \cdot 108(0 \cdot 010) \mathrm{ml} / \mathrm{ml}$ in normal lung 


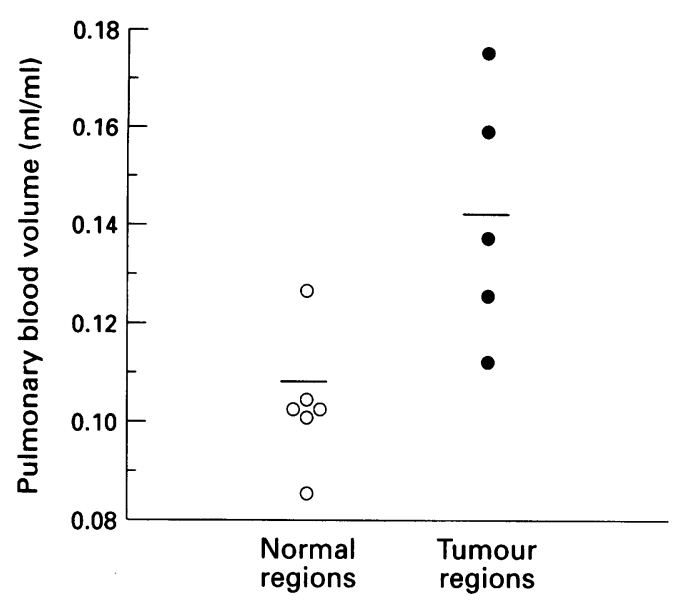

Figure 3 Pulmonary blood volume in normal lung and tumour regions. Horizontal bars represent mean values.

The blood volume was higher in the tumour regions than in the corresponding normal lung regions $(p<0 \cdot 05)$.

regions (fig 3) - a difference of $31 \%(p<0.05)$. The mean $(95 \%$ confidence interval (CI)) for the differences between tumour and normal regions was $0.034(0.005$ to 0.063$) \mathrm{ml} / \mathrm{ml}$.

\section{EXTRAVASCULAR TISSUE DENSITY}

Extravascular tissue density was always higher in tumour regions than in normal lung regions in every subject. The mean value of the extravascular tissue density for the group was 0.653 $(0 \cdot 133) \mathrm{g} / \mathrm{ml}$ in tumour regions which was much higher than the $0.157(0.021) \mathrm{g} / \mathrm{ml}$ in normal lung regions $(p<0.001)$ (fig 4$)$. The mean $(95 \% \mathrm{CI})$ for the differences between tumour and normal regions was $0.496(0.346$ to $0 \cdot 646) \mathrm{g} / \mathrm{ml}$.

\section{$\beta$ ADRENOCEPTOR DENSITY}

The density of $\beta$ receptors was lower in tumour regions than in normal lung regions in every subject, irrespective of the histopathological type. The mean $\beta$ receptor density for the group was $5 \cdot 1(1 \cdot 8) \mathrm{pmol} / \mathrm{g}$ in tumour regions and 9.9

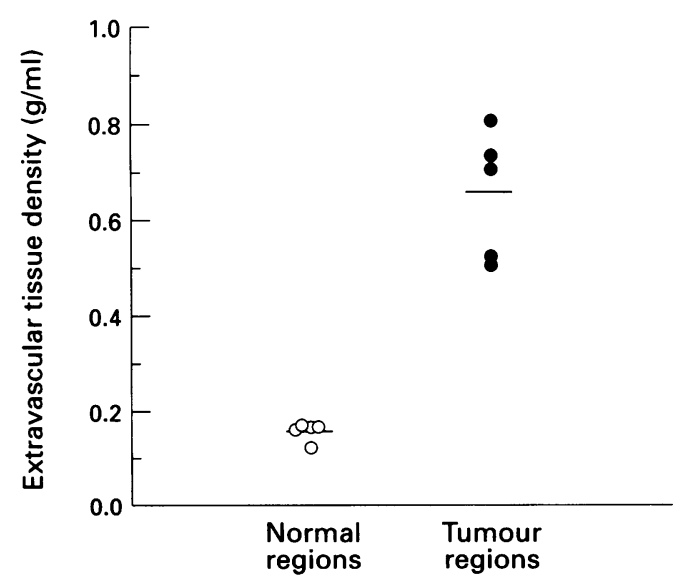

Figure 4 Extravascular lung tissue density in normal lung and tumour regions. Horizontal bars represent mean values $(p<0.001)$.

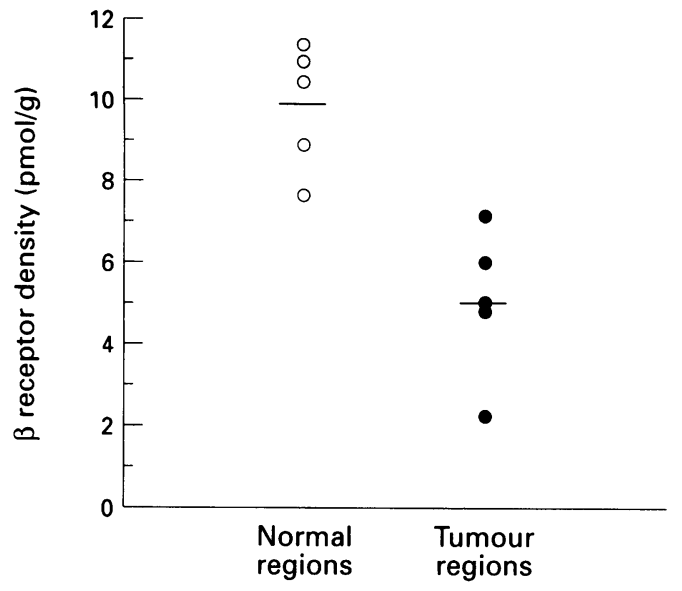

Figure $5 \quad \beta$ adrenoceptor density expressed as pmol/g tissue in normal lung and tumour regions. Horizontal bars represent mean values $(p<0 \cdot 01)$.

(1.6) $\mathrm{pmol} / \mathrm{g}$ in normal lung regions (fig 5 ) - a difference of $48 \%(p<0 \cdot 01)$. The mean $(95 \%$ CI) for the differences between tumour and normal regions was $4.8(2 \cdot 2$ to $7 \cdot 4) \mathrm{pmol} / \mathrm{g}$.

\section{Discussion}

RECEPTOR DENSITY IN TUMOURS

In vivo studies on $\beta$ receptors in patients with lung cancer have not previously been reported due to the lack of suitable methods. We report here the first in vivo study which shows fewer $\beta$ receptors in human lung neoplastic tissue. The reduced numbers of $\beta$ receptors in neoplastic tissue found in the present study are consistent with previously reported in vitro studies.

The earlier studies relied mainly on in vitro measurements on either cultured neoplastic cell lines or resected lung tissue obtained at thoracotomy. Lange-Carter and colleagues ${ }^{8} \mathrm{ex}-$ amined $\beta$ receptor density in cultured neoplastic and normal mouse lung epithelial cells. They reported fewer $\beta$ adrenergic receptors in neoplastic E9 and PCC4 cell membranes ( 6.5 and $12 \mathrm{fmol} / \mathrm{mg}$ protein, respectively) than in normal C10 cell membranes $(37 \mathrm{fmol} / \mathrm{mg}$ protein). Kondratenko and colleagues ${ }^{9}$ measured $\beta$ receptor densities in normal lung tissue (obtained at segmental resection of patients with tuberculoma) and neoplastic lung tissue (obtained from patients with pulmonary adenocarcinoma). The $\beta$ receptor density was only $84 \mathrm{fmol} / \mathrm{mg}$ protein in the neoplastic tissue compared with $456 \mathrm{fmol} / \mathrm{mg}$ protein in normal lung tissue.

MEASURED IN VIVO VALUES

Pulmonary blood volume ( $\mathrm{ml}$ blood/ml thorax) was $31 \%$ higher in the tumour regions than in surrounding normal lung tissue, but when normalised for the tissue occupancy (blood volume/g extravascular tissue) the blood volume was $0.23 \mathrm{ml} \mathrm{blood} / \mathrm{g}$ tissue in tumour regions and $0.65 \mathrm{ml} \mathrm{blood} / \mathrm{g}$ tissue in normal lung regions. Although an interrelationship between regional pulmonary blood volume and blood flow has been reported, ${ }^{19}$ the interpretation of 
these differences in blood volume between the tumour and normal lung regions is still difficult, since the major role of pulmonary blood flow is not nutritional but for gas exchange and the vascular structure in tumour tissue is usually distorted.

The higher value of tissue density in tumour regions reflects the fact that the tissue occupancy in lung cancer tissue is higher than in normal lung tissue which contains a large proportion of air. We recently studied a group of 17 normal subjects to assess the effect of salbutamol on pulmonary $\beta$ adrenoceptors. ${ }^{20}$ In that group, which was younger than the group in the present study (37 (9) years compared with 58 (10) years), the values of blood volume, extravascular tissue density, and $\beta$ adrenoceptor density were $0.151(0.020) \mathrm{ml} / \mathrm{ml}$, $0.182(0.044) \mathrm{g} / \mathrm{ml}$, and $10 \cdot 7(2 \cdot 0) \mathrm{pmol} / \mathrm{g}$, respectively, compared with the corresponding values of $0.108(0.010) \mathrm{ml} / \mathrm{ml}, 0.157(0.021) \mathrm{g} /$ $\mathrm{ml}$, and $9.9(1.6) \mathrm{pmol} / \mathrm{g}$ obtained for the "normal" regions in the present study. The values for extravascular tissue density and density of $\beta$ adrenoceptors were close between the two groups, whereas the value for the blood volume is rather lower in the older group of patients. Whether this difference is due to the ageing effect or due to the tumour itself (neoplastic tissue might release some substances that could affect the blood volume in the adjacent normal lung tissue) is unclear.

\section{$\beta$ RECEPTORS AND MALIGNANCY \\ $\beta$ receptors and $c A M P$}

The $\beta$ adrenergic receptor forms the frontier unit in the $\beta$ receptor, $G$ protein, adenylate cyclase, cyclic $3^{\prime}, 5^{\prime}$-adenosine monophosphate (cAMP) and protein kinase chain which forms one of the most important second messenger systems. Besides $\beta$ receptor agonists, numerous other reagents such as cholera toxin, forskolin and prostaglandin $\mathrm{E}$ can also increase the cellular cAMP level. ${ }^{21} \mathrm{~A}$ number of growth factors utilise the same signal transduction pathways as $\beta$ receptors - for example, platelet derived growth factor (PDGF) has been reported to elicit cAMP accumulation in Swiss 3T3 cells. ${ }^{22}$ cAMP is an important modulator of cellular growth and differentiation. ${ }^{23}$ The intracellular cAMP level fluctuates at different stages of the cell cycle. The most common finding is that the cAMP level is at a minimum during mitosis, gradually increases during $G_{1}$ (Gap 1, period between mitosis and the start of DNA synthesis), reaches a peak near the $G_{1}-S$ border, and declines again during the $S$ phase (DNA synthesis). ${ }^{23}$ Addition of exogenous cAMP to various cultured cell types has demonstrated both an inhibiting and a stimulating effect on proliferation. ${ }^{24}$ cAMP might modulate the activity of various oncogenes and growth factors. The ultimate response to cAMP would then depend upon the cell types, the oncogene driving its growth, the dose of cAMP, and the environment of the cells. ${ }^{24}$ Alterations in any step in the cAMP synthesis pathway might therefore result in a malfunction of the regulation of cell proliferation and differentiation.

\section{Potential therapeutic implications}

Changes in $\beta$ adrenoceptors could affect intracellular cAMP levels which might, in turn, affect the growth and differentiation or quiescence of a cell. The finding of a reduced $\beta$ adrenoceptor density in neoplastic tissue provides an opportunity for potential therapeutic intervention. cAMP has been reported to inhibit the growth of small cell lung cancer cell lines. ${ }^{25} \mathrm{~A}$ low receptor density might therefore be indicative of a deficient cAMP production with a resulting diminution in the regulation of cell growth and differentiation. In certain types of cancer in which cAMP exerts a negative effect on growth, this might contribute to further neoplastic progression. As stated above, a number of agents can increase the cAMP level. The possibility therefore exists of employing these agents to restore cAMP levels. This has already been tested in cultured cell lines and in animal preparations. An early study by Chelmika-Schorr and coworkers demonstrated that growth of a C- 6 glioma was suppressed in rats treated with the $\beta$ receptor agonist isoprenaline. Addition of papaverine, a cAMP phosphodiesterase inhibitor, to the treatment augmented this effect. Because of the extremely complicated role of cAMP in modulating the growth and differentiation of cells, it is premature to say if this kind of intervention is applicable to humans.

The lower $\beta$ receptor density could itself be the result of the neoplastic process. This may be due to a number of reasons. Firstly, proliferation of connective tissue (related to tissue repair or inflammation) may increase the receptor-deficient or receptor-lacking cell types, which together with oedema might contribute to the lower numbers of receptors per gram of tissue. However, this is unlikely to be the complete explanation of our results since most of the tissue assessed histologically was neoplastic. Definite fibrosis and necrosis were found only in one of three patients and inflammation was found only in two of three patients (table), whereas the lower receptor density was observed in every subject. Secondly, neoplastic cells are genetically defective and poorly differentiated. Thus, the expression and synthesis of $\beta$ receptors in these "premature" cells are poor and might result in lower receptor numbers per cell. Gope and colleagues $^{26}$ have reported alterations in the $\beta_{2}$ adrenergic receptor gene in some colorectal cancers. Hughes and colleagues ${ }^{27}$ reported that the $\beta_{2}$ adrenergic receptor deficient S49 lymphoma cells expressed reduced quantities of $\beta_{2}$ receptor specific mRNA although they contained the same amount of the $\beta_{2}$ receptor gene as the control cells. In their studies the amount of $\beta_{2}$ adrenergic receptor specific mRNA correlated very well with the reduction in receptor expression in these cells. They believe that the relative paucity of gene transcripts is responsible for the diminution of the receptors.

In summary, the present studies using PET as a new tool have found that $\beta$ adrenergic receptor density in vivo was considerably reduced in five lung tumours. This is unlikely to be solely explained by fibrosis, necrosis or 
inflammation, and suggests a lower number of $\beta$ receptors per neoplastic cell.

The authors thank A D Williams, A R K Blyth, and the personnel of the blood counting laboratory and the radiochemistry and cyclotron operations groups for their assistance in performing
the PET scans. This work was supported by the National Asthma Campaign, Allen and Hanburys Ltd, and the British Lung Foundation.

1 Chelmicka-Schorr E, Arnason BGW, Holshouser SJ. C-6 glioma growth in rat: suppression with a $\beta$-adrenergic agonist and a phosphodiesterase inhibitor. Ann Neurol 1980;8:447-9.

2 Cho-Chung YS, Clair T, Tagliaferri P, Ally S, Katsaros D, Tortora G, et al. Site-selective cyclic AMP analogs as new biological tools in growth control differentiation, and biological tools in growth control, differentiation, and

3 Paul-Eugene N, Dugas B, Gordon J, Kolb JP, Cairns JA, Paubert-Braquet JM, et al. $\beta_{2}$-adrenoceptor stimulation augments the IL-4-induced CD23 expression and release and the expression of differentiation markers (CD14, CD18) by the human monocytic cell line, U937. Clin Exp Allergy 1993;23:317-25.

4 Bang BE, Aarbakke J, Sager G. Epinephrine induces $\beta$ adrenergic desensitization and differentiation of $\mathrm{HL}-60$ cells. Scand 7 Clin Lab Invest 1993;53:331-5.

5 Kinnard RL, Chelmicka-Schorr E, Checinski ME, Jones $\mathrm{KH}$, Arnason BGW. Sympathetic nervous system and glioma growth. Eur $\mathcal{f}$ Cancer Clin Oncol 1986;22:501-3.

6 Chelmicka-Schorr E, Sportiello MG, Atweh SF, Arnaso $\mathrm{BGW}$. Response of C-6 glioma to isoproterenol and papaverine in vivo depends on $\beta$-adrenergic receptor density. Ann Neurol 1984;15:96-9.

7 D'Amico C, Crescimanno M, Armata MG, Leonardi V, Palazzoadriano M, D'Alessandro N. Beta-adrenergic influences on doxorubicin-sensitive or -resistant p388 leukemia cells. Anticancer Res 1992;12:2253-6.

8 Lange-Carter CA, Droms KA, Vuillequez JJ, Malkinson AM. Differential responsiveness to agents which stimulate cAMP production in normal versus neoplastic mouse lung epithelial cells. Cancer Lett 1992;67:139-44.

9 Kondratenko TY, Zacharova IV, Kuzina NV, Katukov VY, Severin ES, Kornilova ZC, et al. Alterations in human lung adrenergic receptors in cancer. Biochem Mol Biol Imt 1993;29:123-30.

10 Koh WJ, Griffin TW, Rasey JS, Laramore GE. Positron emission tomography. A new tool for characterization of malignant disease and selection of therapy. Acta Oncol 1994;33:323-7.

11 Mintun MA, Welch MJ, Siegel BA, Mathias CJ, Brodack $\mathrm{JW}, \mathrm{McGuire} \mathrm{AH}$, et al. Breast cancer: PET imaging of estrogen receptors Radiology 1988;169:45-8.

12 Ueki J, Rhodes CG, Hughes JMB, Silva RD, Lefroy DC, Ind $\mathrm{PW}$, et al. In vivo quantification of pulmonary $\beta$ - adrenoceptor density in humans with (S)-[" $\mathrm{C}]$ CGP 12177 and PET. F Appl Physiol 1993;75:559-65.

13 Rhodes CG, Wollmer P, Fazio F, Jones T. Quantitative measurement of regional extravascular lung density using positron emission and transmission tomography. 7 Compu Assist Tomogr 1981;5:783-91.

14 Brady F, Luthra SK, Tochon-Danguy H-J , Steel CJ, Water $\mathrm{SL}$, Kensett MJ, et al. Asymmetric synthesis of a precursor for the automated radiosynthesis of $\mathrm{S}-\left[{ }^{11} \mathrm{C}\right] \mathrm{CGP} 12177$ as a preferred radioligand for $\beta$-receptors. Appl Radiat Isot 1991;42:621-8.

15 Delforge J, Syrota A, Lancon J-P, Nakajima K, Janier CLM Vallois J-M, et al. Cardiac beta-adrenergic receptor density measured in vivo using PET, CGP 12177 and a new graphical method. F Nucl Med 1991;32:739-48.

16 Robb RA, Hanson DP. A software system for interactive and quantitative visualization of multidimensional biomedical images. Australas Phys Eng Sci Med 1991;14:9-30.

17 Qing F, Rhodes CG, Hayes MJ, Ind PW, Krausz T, Fountain $\mathrm{SW}$, et al. In vivo quantification of human pulmonary $\beta$ adrenoceptor density using PET: comparison with in vitro radioligand binding. $f \mathrm{Nucl} \mathrm{Med} 1996$ (in press).

18 Merlet P, Delforge J, Syrota A, Angevin E, Maziere B, Crouzel C, et al. Positron emission tomography with " $\mathrm{C}$ CGP-12177 to assess $\beta$-adrenergic receptor concentration in idiopathic dilated cardiomyopathy. Circulation 1993;87: in idiopathic

19 Brudin LH, Rhodes CG, Valind SO, Jones T, Hughe $\mathrm{JMB}$. Interrelationship between regional blood flow, blood volume, and ventilation in supine humans. 7 Appl Physiol 1994;76:1205-10.

20 Hayes MJ, Qing F, Rhodes CG, Ind PW, Sriskandan S, Jones $\mathrm{T}$, et al. In vivo quantification of pulmonary $\beta$ adrenoceptor: effects of $\beta$-agonist therapy. Am $\mathcal{\exists}$ Respir Crit Care Med 1996 (in press).

21 Rozengurt E. Early signals in the mitogenic response. Science 1986;234:161-6.

22 Rozengurt E, Stroobant P, Waterfield MD, Deuel TF Keehan M. Platelet-derived growth factor elicits cyclic AMP accumulation in Swiss 3T3 cells: role of prostaglandin production. Cell 1983;34:265-72.

23 Beebe SJ, Corbin JD. Cyclic nucleotide-dependent protein kinases. In: Boyer PD, Krebs EG, eds. The enzymes. Orlando: Academic Press, 1986;17:44-114.

24 Gottesman MM, Fleischmann RD. The role of cAMP in regulating tumor cell growth. Cancer Surv 1986;5: 291-308.

25 Khan MZ, Freshney RI, McNicol AM, Murray AM. Induction of phenotypic changes in SCLC cell lines in vitro by hexamethylene bisacetamide, sodium butyrate, and cAMP. Ann Oncol 1993;4:499-507.

26 Gope R, Gope ML, Thorson A, Christensen M, Smyrk T, Chun $M$, et al. Genetic changes at the beta-2-adrenergic receptor locus on chromosome 5 in human colorectal receptor locus on chromosome 5 in human

27 Hughes RJ, Howard MJ, Allen JM, Insel PA. Decreased $\beta_{2}$ adrenergic receptor mRNA expression in recepto deficient S49 lymphoma cells. Mol Pharmacol 1991;40 974-9. 